\title{
Biorreceptividad de las dolomías a la colonización fúngica
}

\section{Dolostone bioreceptivity to fungal colonization}

\author{
B. Cámara(*), A. De los Ríos(*), M.A. García-del-Cura(**), V. Galván(***) y C. Ascaso(*)
}

Recepción/Received: 15-V-07

Aceptación/Accepted: 11-X-07

Publicado online/Online publishing: 10-XII-07

\section{RESUMEN}

En este trabajo se evalúa cómo influye la textura de las dolomías en las estrategias adoptadas por los microorganismos para colonizar estos materiales pétreos. Para ello se han caracterizado muestras de dolomías con diferentes texturas mediante microscopía electrónica de barrido en modo de electrones retrodispersados (SEM-BSE), microscopía electrónica de barrido a bajas temperaturas (LTSEM), microscopía de luz transmitida (TLM) y porosimetría por intrusión de mercurio (MIP). De estas observaciones se deduce que los hongos son los microorganismos colonizadores más importantes en las dolomías estudiadas. Además, en esta colonización fúngica se han distinguido tres fases bien definidas que tienen como resultado final la disgregación completa de la roca. La presencia y extensión de cada fase de colonización se han visto determinadas por la magnitud y tipo de porosidad de las distintas dolomías analizadas. Los resultados de este estudio apuntan a que estas características de textura pueden condicionar la biorreceptividad de las dolomías y por tanto también los procesos de alteración asociados a esta colonización.

Palabras clave: biorreceptividad, dolomías, estrategias de colonización, hongos litobiónticos, textura de las rocas.

\section{SUMMARY}

In many historic monuments in which signs of biodeterioration have been frequently reported, dolostones were used as dimension stone for their construction. In an effort to assess the influence of the texture of dolostones on their potential bioreceptivity, we characterized microbial colonization strategies in dolostone samples of predictably different textural features by scanning electron microscopy in back scattered electron mode (SEM-BSE), low temperature scanning electron microscopy (LTSEM), transmission light microscopy (TLM) and mercury intrusion porosimetry (MIP). Fungi were the predominant microorganisms in the dolostones examined and their colonization showed three well defined stages with the final consequence of complete rock disaggregation. The results of this study indicate that porosity differences (mainly the extent and type) were particularly relevant for determining the presence and extent of each colonization stage. As a determinant of bioreceptivity, the porosity of dolostones will also condition the decay processes associated with this colonization.

Keywords: bioreceptivity, dolostones, colonization strategies, lithobiontic fungi, stone textures.

(*) Centro de Ciencias Medioambientales (CSIC)

(**) Instituto de Geologia Económica CSIC-UCM.

(***) Universidad SEK. 


\section{INTRODUCCIÓN}

A lo largo de la historia de la humanidad, las dolomías se han convertido en un material de construcción muy valorado para el Patrimonio Arquitectónico. Este tipo de roca ha sido empleada como piedra de fábrica en la construcción de muchos monumentos históricos (1-3), debido especialmente a sus propiedades de durabilidad y fácil labra y por su amplia distribución geográfica. En muchos de los monumentos históricos construidos con dolomías que han perdurado hasta nuestros días, es posible observar fenómenos de deterioro sobre sus superficies (4). Esta alteración de la piedra monumental se debe no sólo a los efectos generados por los agentes físicos y químicos, sino que también la colonización biológica puede estar implicada en estos procesos, y adquirir un papel clave (5). La piedra puede estar colonizada tanto en superficie (epilítica) como en zonas más internas (endolítica) y contener microorganismos de grupos muy diversos entre los que se encuentran bacterias quimioorganótrofas y quimiolitótrofas, cianobacterias, algas, hongos tanto de vida libre como liquenizados (6). Estos microorganismos pueden provocar alteraciones graves en la roca como consecuencia de las interacciones geofísicas y geoquímicas complejas que establecen con el sustrato lítico (7). El desarrollo de las comunidades litobiónticas puede estar determinado por los requerimientos específicos de los microorganismos constituyentes (8), pero también por otras características físico-químicas del sustrato lítico colonizado como es la composición química y la petrofábrica (9). De hecho, la textura de las rocas ha sido propuesta como una de las propiedades con mayor influencia sobre la biorreceptividad (10), es decir, sobre la potencialidad de una roca para ser colonizada por distintos microorganismos u organismos. En el campo del biodeterioro de monumentos en los últimos años, propiedades físico-químicas del material pétreo, tales como rugosidad, porosidad y naturaleza mineralógica, están siendo consideradas como factores determinantes de su biorreceptividad, y por tanto de su colonización microbiana (11-14).

En este trabajo se evalúa la influencia de la textura de las dolomías en la colonización que sufren por hongos litobiónticos a través de un análisis combinado de técnicas de microscopía (TLM, SEM-BSE y LTSEM) y porosimetría por intrusión de mercurio (MIP). Con ello se quiere caracterizar la biorreceptividad potencial de estas rocas y contribuir al conocimiento actual de los procesos de biodeterioro en monumentos históricos construidos con dolomía.

\section{MATERIAL Y MÉTODOS}

\subsection{Material}

Para llevar a cabo este estudio, se recogieron muestras de dolomías con intensa colonización biológica y con pre-

\section{INTRODUCTION}

As reflected in our architectural heritage, dolostone has been a valuable building stone throughout the course of human history. Dolostone was used as dimension stone in the construction of many historic monuments (1-3) owing to its unique properties such as good workability, durability and broad distribution across the Earth's surface. Although many of these dolostone monuments still stand today, signs of deterioration processes on their stone surfaces have been frequently reported (4). Besides physical and chemical agents, it is well-known that biological colonization plays a major role in rock decay (5). As common inhabitants of the rock surface (epilithic microorganisms) and even the rock interior (endolithic microorganisms), we find a high microbial diversity in the form of chemoorganotrophic and chemolithotrophic bacteria, cyanobacteria, algae and free-living fungi as well as lichenized forms (6). The weathering processes induced by these microorganisms are the consequence of complex geophysical and geochemical interactions with the lithic substrate (7). The development of lithobiontic communities may not only be determined by the properties of their component microorganisms (8) but also by factors related to the physico-chemical properties of the colonized lithic substrate, such as the chemical composition of the rock or its petrofabric (9). The texture of rocks has been proposed to greatly influence their bioreceptivity (10). In other words, textural features can determine the potential or susceptibility a rock has to be colonized by different microorganisms and organisms. The characterization of physico-chemical properties of building materials such as surface roughness, initial porosity and mineralogical nature, has been considered essential for assessing their bioreceptivity and thus their susceptibility to biodeterioration (11-14).

In this study, we examined the possible effects of the texture of dolostone on fungal colonization using a combination of microscopy techniques (TLM, SEM-BSE, LTSEM) and mercury intrusion porosimetry (MIP). Our findings were then used to characterize the potential bioreceptivity of these rocks and contribute to our current understanding of the biodeterioration processes that affect historic buildings made of dolostone.

\section{MATERIALS AND METHODS}

\subsection{Sampling}

Samples of dolostones with visible biological colonization and predictably different textural features were collected 
visiblemente diferentes texturas correspondientes a distintas localizaciones y representativas de distintos estados de colonización microbiana y alteración de la piedra:

a) Tipo D-I, procedentes de un afloramiento geológico muy próximo a la Iglesia Románica La Vera Cruz, Segovia-España. Estas dolomías son del Cretácico Superior y pertenecen a la formación geológica conocida como "Montejo de la Vega".

b) Tipo D-II, procedentes de la Iglesia Románica La Vera Cruz, Segovia. Esta iglesia fue construida a principios del Siglo XIII y restaurada en 1949. Se localiza a las afueras de Segovia, en el barrio árabe de San Marcos. Las dolomías utilizadas en su construcción son de la misma unidad litológica que las que constituyen el afloramiento natural situado en sus proximidades.

c) Tipo D-III, procedentes del Castillo de Biar, AlicanteEspaña. Es una construcción de estilo y origen almohade que aparece citada por primera vez en 1172. El castillo se alza sobre un cerro desde el que domina la localidad que lleva el mismo nombre, situada al norte de la provincia de Alicante. Está construido con mampostería de dolomías cretácicas, alguna caliza tobácea cuaternaria y ladrillo.

\subsection{Microscopía de luz transmitida (TLM)}

Las muestras de rocas para estudiar con microscopio de luz transmitida (TLM) fueron cortadas usando un disco de gran radio lubricado con agua para obtener fragmentos de $30 \times 20 \times 15 \mathrm{~mm}$, y posteriormente impregnadas con un endurecedor epofix (trietilenotetramine) en una cámara de vacío. Una de las caras mayores del fragmento fue pulida con una pulidora automática con carborundo de grano $320 \mathrm{~F}$, seguido de un pulido con grano $600 \mathrm{~F}$ y otro con grano $1000 \mathrm{~F}$. A continuación la cara pulida fue pegada sobre una pieza de vidrio y el fragmento fue cortado a un grosor próximo a $30 \mu \mathrm{m}$ y pulido con carborundo de tamaño de grano $1000 \mathrm{~F}$ y con una pasta de diamante que contenía cristales de $1 / 4 \mu \mathrm{m}$ hasta alcanzar el grosor exacto de $30 \mu \mathrm{m}$. La mitad de cada preparación fue teñida con una disolución ácida de alizarina roja S (que tiñe la calcita de rojo) y ferricianuro potásico que tiñe el carbonato de hierro de azul (15). Finalmente, estas secciones delgadas fueron examinadas mediante un microscopio de luz transmitida Zeiss Axioscop.

\subsection{Porosimetría por intrusión de mercurio (MIP)}

La porosimetría de mercurio fue utilizada para caracterizar el sistema poroso de muestras de dolomías homogéneas de un tamaño de $1,5 \mathrm{~cm} \times 2,5 \mathrm{~cm}$ mediante su porosidad conectada determinando la distribución de tamaños de from sites representative of different colonization and weathering stages of the stone.

a) Type D-I: taken from a natural outcrop close to the Romanesque Church of La Vera Cruz, Segovia-Spain. These dolostones (Upper Cretaceous) belong to the geologic formation known as "Montejo de la Vega".

b) Type D-II: from the Romanesque Church of La Vera Cruz, Segovia-Spain. This Romanesque church was built at the start of the XIII Century, using dolostone from the same lithological unit as that of the natural outcrop in the area, and restored in 1949. La Vera Cruz may be found in the Arab quarters of San Marcos on the outskirts of Segovia, on the road to Zamarramala.

c) Type D-III: from Biar Castle, Alicante-Spain. The first published reference to this Almohad-style construction dates back to 1172 . From its strategic position on a hill, the castle dominates the locality with which it shares its name, in the north of Alicante province. Its building materials are cretaceous dolostone masonry with some Quaternary limestone and brick.

\subsection{Transmitted light microscopy (TLM)}

Rock samples for TLM were trimmed using a large-radius blade lubricated with water to obtain $30 \times 20 \times 15 \mathrm{~mm}$ fragments, which were then impregnated with epofix hardener (triethylenetetramine) in a vacuum chamber. One rock face was lapped smooth using an automatic lapping machine and carborundum $320 \mathrm{~F}$ followed by grades 600 $F$ and $1000 \mathrm{~F}$. Next, the polished side was stuck onto a large piece of glass and cut down to $5 \mathrm{~mm}$. After placing back in the machine and cutting down to $30 \mu \mathrm{m}$, it was polished using $1000 \mathrm{~F}$ grade carborundum and a high performance diamond product containing $1 / 4 \quad \mu m$ polycrystalline diamonds. Half the samples were then stained with an acid alizarin red $S$ solution (staining calcite red) and potassium ferricyanide which stains ferrous carbonate blue (15). An Axioscop (Zeiss) transmitted light microscope was used to examine these thin sections.

\subsection{Mercury intrusion porosimetry (MIP)}

Mercury porosimetry was used to characterize the pore systems of homogeneous dolostone samples $(1.5 \mathrm{~cm} x$ $2.5 \mathrm{~cm}$ ) in terms of their connected porosity, pore size distribution and mean pore size. Pore size ranged from 
poros y el tamaño medio de poro en un rango desde $0,0003 \mu \mathrm{m}$ a $200 \mu \mathrm{m}$. El equipo usado fue un porosimetro Micromeritics con una presión de intrusión de mercurio de 0,015 a $250 \mathrm{MPa}$. La densidad aparente de una roca o masa volúmica, $\rho_{\text {bulk }}$, se define como la relación masa/volumen, incluyendo el volumen de huecos y de sólido. Puede estimarse por porosimetría de mercurio a baja presión (0,0030 MPa). Mientras que, la densidad real (densidad de la fracción sólida), $\rho_{\text {real }}$, definida como la relación de la masa y el volumen del sólido, puede ser obtenida usando un picnómetro de helio. La porosidad total ha sido calculada utilizando los datos de porosimetría de mercurio y porosimetría de helio según la siguiente ecuación [1] (16):
0.0003 to $200 \mu \mathrm{m}$. The equipment used was an Autopore IV 9500 Micromeritics porosimeter with a mercury intrusion pressure range of 0.015-250 MPa. The bulk density of a rock, $\rho_{\text {bulk }}$, is defined as the mass to volume ratio, including the volume of voids and solid. It may be estimated by mercury porosimetry at a low head pressure $(0.0030 \mathrm{MPa})$. The real density (the density of the grains), $\rho_{\text {real }}$, is defined as the ratio of mass to solid volume and can be obtained using a helium pyknometer. Total porosity was calculated by combining the mercury porosimetry and helium pyknometry data in the following equation [1] (16):

$$
P_{T}(\%)=\left(1-\frac{\rho_{\text {bulk }}}{\rho_{\text {real }}}\right) \times 100
$$

La porosidad total $\mathrm{P}_{\mathrm{T}}(\%)$ incluye la porosidad abierta $\mathrm{y}$ la porosidad cerrada. La porosidad abierta incluye el volumen de poros accesibles para una molécula dada (en este caso helio y mercurio) y la porosidad cerrada es el volumen de poros aislados dispersos en el medio.

\subsection{Microscopía electrónica de barrido en modo de electrones retrodispersados (SEM-BSE)}

Pequeños fragmentos de dolomías, extraídos de superficies verticales de los monumentos y del afloramiento natural, fueron preparados para observar la interfase microorganismo-roca a través del microscopio electrónico de barrido en modo de electrones retrodispersados (SEMBSE) y por espectroscopía por energía dispersiva de rayos $X$ (EDS) siguiendo un procedimiento especial "técnica SEM-BSE" descrito por (17). Para ello, en primer lugar se llevó a cabo la fijación de los fragmentos de roca con glutaraldehido (3,25\% en tampón cacolidato $0,05 \mathrm{M})$, seguida de una fijación con tetróxido de osmio (1\% en tampón cacolidato $0,025 \mathrm{M})$. Después de una deshidratación en una serie creciente de soluciones etanol, las muestras fueron incluidas en resina LR-White, finamente pulidas y recubiertas con carbón. Finalmente, las superficies pulidas de las muestras fueron observadas utilizando un microscopio electrónico de barrido (SEM) Zeiss DMS 960 equipado con un detector semiconductor de electrones retrodispersados (BSE) y con un sistema microanalítico ISIS Link EDS.

\subsection{Microscopía electrónica de barrido a bajas temperaturas (LTSEM)}

La observación de las muestras rocosas por LTSEM se llevó a cabo de acuerdo al procedimiento descrito por (18). Los fragmentos de dolomía, previamente hidratados, fueron fijados mecánicamente con un adhesivo
Total porosity $P_{T}(\%)$ includes open porosity and closed porosity. Open porosity is the volume of pores accessible to any given molecule (in this case helium and mercury) and closed porosity is the volume of isolated pores dispersed across the medium.

\subsection{Scanning electron microscopy in back scatte- red electron mode (SEM-BSE)}

Fragments of dolostone, collected from vertical faces of the monuments and natural outcrop, were prepared for observing the rock-microorganism interface by scanning electron microscopy (SEM) and energy dispersive $X$-ray spectroscopy (EDS) according to the "SEM-BSE technique" described elsewhere (17). First, hand-cut pieces of rock were fixed in glutaraldehyde $(3.25 \%$ in $0.05 \mathrm{M}$ cacolidate buffer) and then in osmium tetroxide (1\% in 0.025 $M$ cacolidate buffer). Following dehydration in a graded series of ethanol solutions, the samples were embedded in $L R-$ White resin, finely polished and carbon-coated. Samples were observed in a Zeiss DMS 960 SEM equipped with a four-diode, semiconductor BSE detector and an ISIS Link EDS microanalytical system.

\subsection{Low temperature scanning electron micros- copy (LTSEM)}

Fragments of rock were examined by LTSEM according to a previously described procedure (18). In brief, small fragments were mounted using O.C.T. compound (Gurr) and mechanically fixed onto the specimen holder of the 
especial O.C.T. compound (Gurr) a un portamuestras y transferidos al sistema de criotransferencia (Oxford1500). Rápidamente las muestras fueron congeladas por inmersión en nitrógeno líquido subenfriado y transferidas a la unidad de preparación del microscopio. En el interior de esta cámara las muestras ultracongeladas fueron criofracturadas y después transferidas directamente al microscopio donde se elevó la temperatura a $-90^{\circ} \mathrm{C}$ durante 2 min ("etching"). Después de la sublimación, las superficies fracturadas fueron recubiertas con oro y transferidas a la cámara fría del microscopio DSM 960 Zeiss para llevar a cabo su observación a $-135^{\circ} \mathrm{C}$.

\section{RESULTADOS Y DISCUSIÓN}

En todas las muestras analizadas (Tipos D-I, D-II, D-III), el componente mineralógico fundamental resultó ser la dolomita ( $\mathrm{CaMg}\left(\mathrm{CO}_{3}\right)_{2}$ en forma de cristales euhedrales y subhedrales. Asimismo, se detectó la presencia de calcita en cantidades variables (correspondientes a indicios de dedolomitización) y la presencia de minerales arcillosos y granos de cuarzo y feldespato potásico en menor proporción. Sin embargo, los distintos tipos de dolomías mostraron diferencias en el tamaño de los cristales dolomíticos y en la extensión y tipo de porosidad. Las dolomías tipo D-I y D-II revelaron un tamaño medio de los cristales dolomíticos de 30 a $60 \mu \mathrm{m}$, mientras que las dolomías tipo D-III mostraron cristales de mayor tamaño (Figura 1-3). En cuanto a la porosidad, las dolomías D-I se caracterizaron por valores altos de porosidad inter- (Figura 1A) e intracristalina (Figura 1B), las dolomías D-II por una alta cryotransfer system (Oxford CT1500). These samples were plunge-frozen in subcooled liquid nitrogen and then transferred to the microscope's preparation unit. The frozen specimens were cryofractured and etched for 2 minutes at $-90^{\circ} \mathrm{C}$. After ice sublimation, the etched surfaces were gold sputter coated and transferred onto the cold stage of the SEM chamber. Fractured surfaces were observed under a DSM 960 Zeiss SEM microscope at $-135^{\circ} \mathrm{C}$.

\section{RESULTS AND DISCUSSION}

The predominant mineral in all the rock samples analysed (Types D-I, D-II, D-III), was dolomite $\left(\mathrm{CaMg}\left(\mathrm{CO}_{3}\right)_{2}\right.$ in the form of euhedral and subheudral crystals, along with variable quantities of calcite (indicating a dedolomitization process). Clay minerals and quartz and potassium feldspar grains appeared in minor quantities. Using the TLM and SEM-BSE techniques, it was possible to detect the presence of medium (between 30 and $60 \mathrm{~mm}$ crystals are presented in D-I and D-II) to large sized crystals of dolostones (D-III) as well as porosity differences among the samples (Figure 1-3). Type D-I was characterized by high inter- (Figure 1A) and intracrystalline porosity values (Figure 1B), while the $D$-II dolostones showed high intercrystalline (Figure $2 A$ ) and low intracrystalline porosity (Figure $2 B$ ) and the $D$-III dolostones exhibited both low inter- (Figure 3A) and intracrystalline porosity (Figure

Tabla 1 / Table 1

Medidas del radio medio del poro, densidad aparente, porosidad y distribución del tamaño del poro de los tres tipos de dolomía analizados (D-I, D-II, D-II) obtenidas mediante porosimetría por intrusión de mercurio (MIP).

Mean pore radius, bulk density, porosity and pore size distribution data determined by mercury intrusion porosimetry on the three different types of dolostone: D-I, D-II and D-III.

\begin{tabular}{|l|c|c|c|}
\cline { 2 - 4 } \multicolumn{1}{c|}{} & \multicolumn{3}{c|}{ Muestras / Samples } \\
\cline { 2 - 4 } \multicolumn{1}{c|}{} & D-I & D-II & D-III \\
\hline $\begin{array}{l}\text { Radio medio del poro }(\mu \mathrm{m}) \\
\text { Mean pore radius }(\mu \mathrm{m})\end{array}$ & 0.29 & 0.52 & 52.29 \\
\hline $\begin{array}{l}\text { Masa volúmica }\left(\tilde{\mathrm{n}}_{\text {bulk }}\right)\left(\mathrm{gml}^{-1}\right) \\
\text { Bulk density }\left(\tilde{n}_{\text {bulk }}\right)\left(\mathrm{gm}^{-1}\right)\end{array}$ & 2.118 & 2.181 & 2.625 \\
\hline $\begin{array}{l}\text { Porosidad } \mathrm{P}(\mathrm{Hg})(\%) \\
\text { Porosity } \mathrm{P}(\mathrm{Hg})(\%)\end{array}$ & 24.1 & 21.9 & 6.50 \\
\hline $\begin{array}{l}\text { Radio del poro } \mathrm{R}(\mu \mathrm{m}) \\
\text { Pore radius } R(\mu \mathrm{m})\end{array}$ & & & \\
\hline $200-100$ & 3.04 & 2.52 & 28.06 \\
\hline $100-10$ & 4.34 & 2.99 & 48.30 \\
\hline $10-1$ & 6.32 & 29.20 & 14.73 \\
\hline $1-01$ & 16.63 & 16.09 & 8.32 \\
\hline $0.1-0.01$ & 0.10 & 4.15 & 0.59 \\
\hline$<0.01$ & & & \\
\hline
\end{tabular}




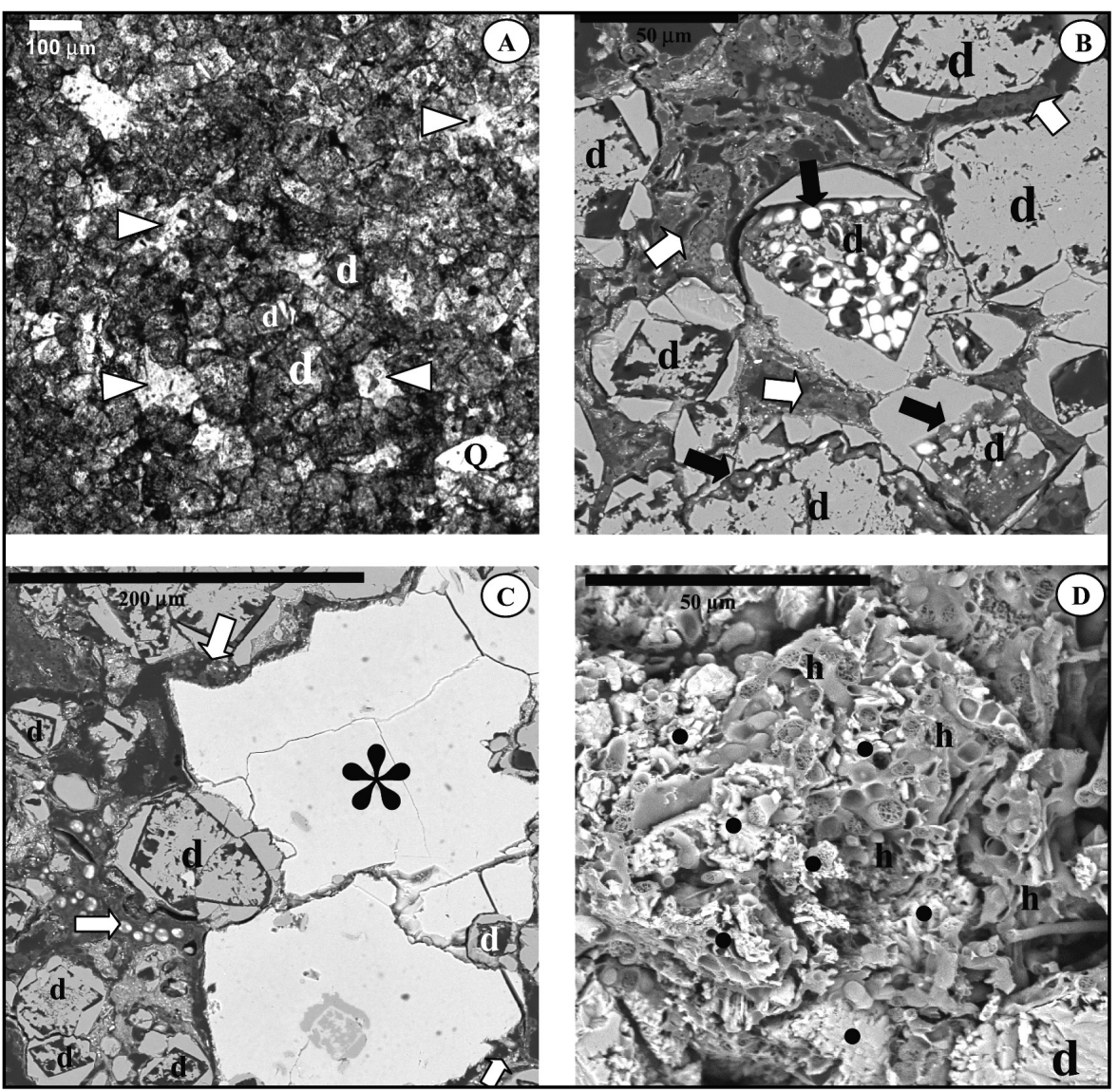

Figura 1. Imágenes de la dolomía tipo D-I caracterizada por una alta porosidad inter- e intracristalina: cristales dolomíticos (d), granos de cuarzo (Q), hongos (h); A) Microfotografía de microscopio de luz transmitida (TLM) mostrando cristales de dolomita de tamaño medio y poros intercristalinos rellenos con resina azul (puntas de flecha); B) Imagen SEM-BSE mostrando la presencia de las hifas fúngicas entre los cristales dolomíticos (flechas blancas) y en el interior de los mismos (flechas negras); C) Imagen de SEM-BSE mostrando células fúngicas (flechas blancas) alrededor de los granos minerales (asterisco); D) Imagen de LTSEM de una masa de hongos englobando pequeños cristales minerales (puntos negros).

Figure 1. Images of D-I dolostone characterized by high inter- and intracrystalline porosity: dolomite crystals (d), quartz grains (Q), fungal hyphae (h); A) TLM micrograph showing the medium-sized dolomite crystals with intercrystalline pores filled with blue resin (arrowheads); B) SEM-BSE image showing fungal hyphae inhabiting spaces between the dolomite crystals (white arrows) and within the crystals (black arrows); C) SEM-BSE image showing fungal cells (white arrows) around mineral grains (asterisk); D) LTSEM image of a fungal tangle with embedded small mineral fragments (black points).

porosidad intercristalina (Figura $2 \mathrm{~A}$ ) y una baja porosidad intracristalina (Figura 2B) y finalmente, la muestra D-III reveló una baja porosidad tanto inter- (Figura 3A) como intracristalina (Figura 3B). Los datos obtenidos del análisis de porosimetría por intrusión de mercurio confirmaron las observaciones realizadas por microscopía. La mayor porosidad total (24,1\% y $21,9 \%$, Tabla 1$)$ fue obtenida en muestras con alta porosidad intercristalina (D-I y D-II), mientras que los valores más bajos $(6,50 \%$, Tabla 1$)$ y el mayor porcentaje de poros grandes tuvieron lugar en la muestra con menor porosidad intercristalina (D-III).

El componente biológico más abundante identificado en las dolomías analizadas fueron los hongos, tanto de vida libre como liquenizados. Estos microorganismos fueron detectados ocupando distintas posiciones dentro de las dolomías, y asociados principalmente a zonas alteradas.
3B). These microscopy observations were confirmed through mercury intrusion porosimetry. Thus, highest total porosity values $(24.1 \%$ and $21.9 \%$, Table 1$)$ were obtained for the samples in which we had observed high intercrystalline porosity ( $D-I$ and $D-I I)$, whereas the sample showing low intercrystalline porosity and the highest percentage of large pores displayed the lowest porosity value (6.50\%, Table 1$)$, was D-III.

The predominant microorganisms observed in the dolostones analysed were both free-living fungi and lichenized fungi. These were observed to occupy different sites in the dolostone associated with altered areas of the rock. In the $D-I$ dolostones, fungal cells inhabited the spaces 


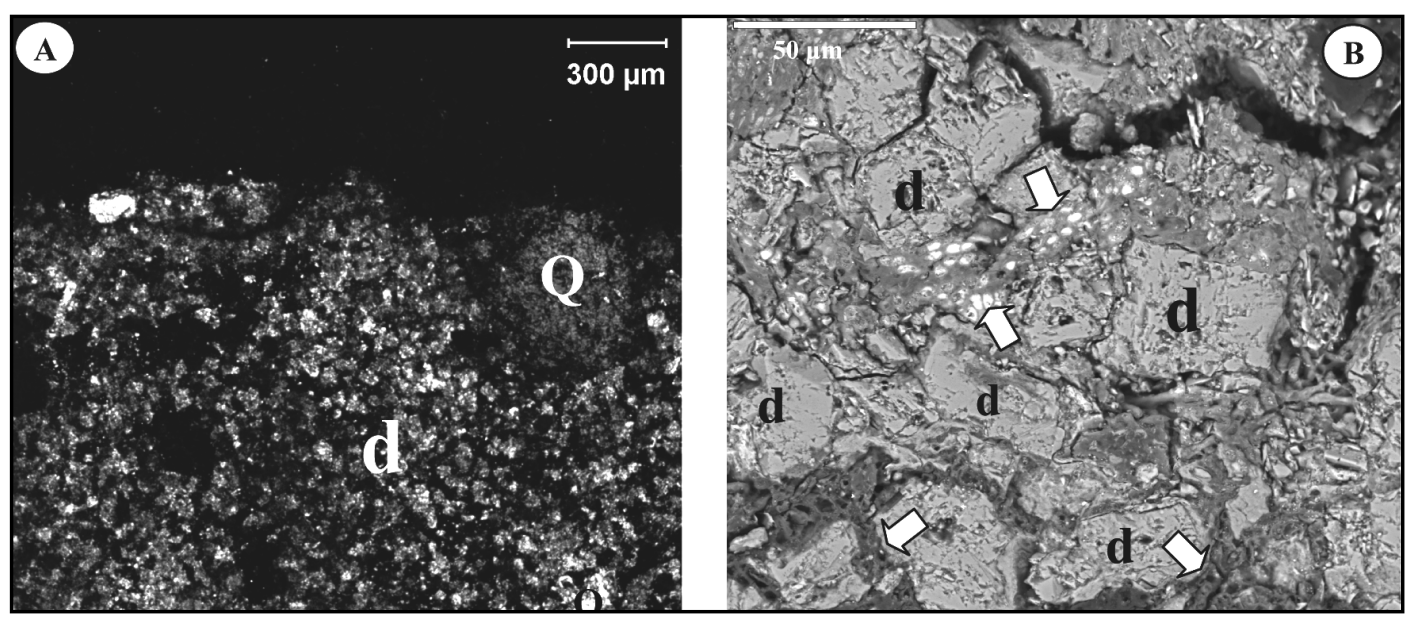

Figura 2. Imágenes de la dolomía tipo D-II caracterizada por una alta porosidad intercristalina y una baja porosidad intracristalina; A) Microfotografía de TLM mostrando cristales dolomíticos de tamaño medio (d) y la presencia de granos de cuarzo (Q) dispersos entre ellos; B) Imagen de SEM-BSE mostrando la colonización fúngica presente en los espacios entre los cristales dolomíticos (flechas blancas) de la dolomía D-II.

Figure 2. Images of D-II dolostone characterized by high intercrystalline and low intracrystalline porosity; A) $T L M$ images showing the dolomite crystals of medium size (d) and the presence of quartz grains (Q) dispersed among them; B) SEM-BSE image of D-II dolostone showing fungal colonization in spaces between the dolomite crystals (white arrows).

En el tipo D-I, los hongos fueron localizados habitando los espacios existentes entre los cristales dolomíticos, en el interior de los mismos (Figura 1B) e incluso también colonizando los alrededores de granos minerales (Figura 1C). Además en algunas áreas de estas dolomías, se pudo apreciar la presencia de masas fúngicas englobando pequeños fragmentos minerales (Figura 1D). En las dolo-mías D-II, sin embargo, estos microorganismos sólo fueron localizados en los espacios existentes entre los cristales dolomíticos (Figura 2B). Y por último, en el tipo D-III, el crecimiento fúngico se registró principalmente asociado a grietas y fisuras ya existentes (Figura 3B). Estos microorganismos litobiónticos han sido capaces de colonizar las dolomías analizadas mediante la combinación de acciones físicas y probablemente químicas sobre el sustrato lítico. La actividad física de los hongos podría ser la predominante a la vista de las imágenes obtenidas en este estudio (Figuras 1B, 1D, 2B), y podría deberse principalmente a las tensiones generadas durante su crecimiento (7) y a las ocasionadas por los cambios de volumen que pueden experimentar debido a su carácter poiquilohídrico (18). Además, también han sido detectados efectos generados por acciones químicas, en forma de depósitos de oxalato cálcico (Figura 4), especialmente en zonas de las dolomías próximas a líquenes epilíticos. La existencia de estos depósitos podría indicar un posible secuestro de iones $\mathrm{Ca}$ procedentes de fragmentos de cristales dolomíticos.

Los resultados mostrados hasta el momento, indican que la distribución de los hongos litobiónticos en las dolomías, parece estar condicionada principalmente por la magnitud y tipo de porosidad de cada muestra analizada. Las between and within the dolomite crystals (Figure 1B) while in other zones they had also colonized spaces around mineral grains (Figure 1C). Moreover, in some areas of these dolostone, numerous hyphae formed a fungal tangle containing small mineral fragments (Figure 1D). In the D-II samples, fungi were detected only in the spaces between dolomite crystals (Figure 2B). Finally, in $D$-III, fungal growth occurred mainly via existing fissures and cracks (Figure 3B). The capacity of fungi to colonize these dolostones could be attributed to a combination of several physical and probably chemical mechanisms. The effects produced by fungal geophysical activity, which seems to be the predominant one, can be inferred from the images obtained in this study (Figures $1 B, 1 D$ and 2B) and are determined mainly by their hyphal mode of growth (7) and by volume changes produced as a consequence of their poikilohydric nature (18). Also detected here were chemical actions in some areas of the dolostones, especially close to epilithic lichens. Oxalate calcium deposits (Figure 4) were observed, indicting possible sequestering of $\mathrm{Ca}$ ions arising from microdivided mineral fragments of dolomite crystals.

The results described above indicate that the extent and type of porosity condition the distribution of the lithobiontic fungi on the rock. Thus, dolostones with high interand intracrystalline porosity (D-I) were more extensively 


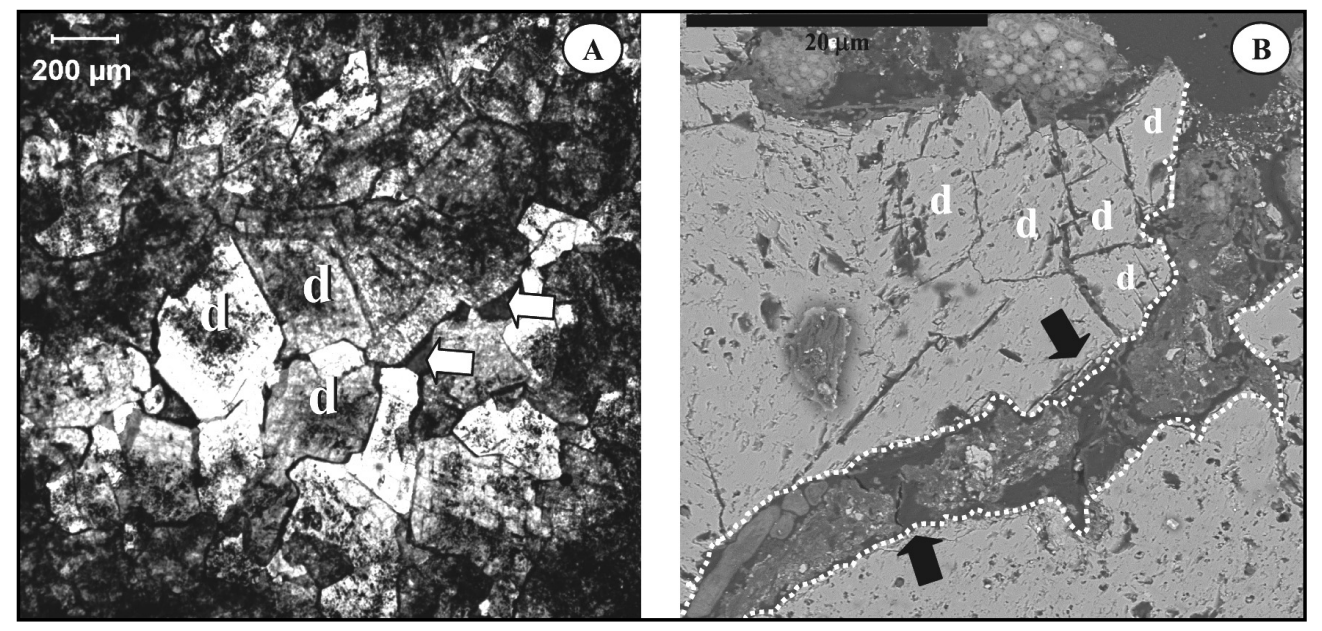

Figura 3. Imágenes de la dolomía tipo D-III caracterizada por una baja porosidad inter- e intracristalina; A) Microfotografía TLM mostrando el tamaño grande de los cristales dolomíticos (d) y la presencia de cemento calcítico teñido con solución de rojo de Alizarina (flechas blancas); B) Imagen SEM-BSE mostrando la colonización microbiana limitada a grietas y fisuras existentes en las dolomías D-III (línea discontinua, flechas negras).

Figure 3. Images of D-III dolostones characterized by low inter- and intracrystalline porosity; A) TLM micrograph showing the large size of the dolomite crystals (d) and the presence of calcite cement stained red with Alizarine solution (white arrows); B) SEM-BSE micrographs showing microbial colonization of the D-III dolostone confined to existing fissures and cracks (broken line, black arrows).

dolomías caracterizadas por una alta porosidad inter- e intracristalina (D-I) mostraron una colonización mayor que aquellas que sólo presentaban una alta porosidad intercristalina (D-II). Con respecto a las dolomías de tipo D-III, su baja porosidad parece determinar una colonización fúngica asociada a una porosidad secundaria. El tamaño del poro es una propiedad intrínseca de las rocas que también podría ser relevante en la colonización biológica especialmente por su relación con la capacidad de retención del agua. En el caso de las dolomías D-III, el alto porcentaje de poros grandes, podría condicionar una baja capacidad de retención del agua y esto, a su vez, determinar también una escasa colonización microbiana $(19,20)$. colonized than those with high intercrystalline porosity but low intracrystalline porosity (D-II). In contrast, the low porosity of the D-III dolostones seems to only allow colonization through secondary porosity. Pore size could be another important property of rocks for biological colonization because of its relationship with water retention capacity. Hence, the low water retention capacity of the large pores in the D-III dolostone samples seemed to prevent extensive microbial colonization (19, 20).

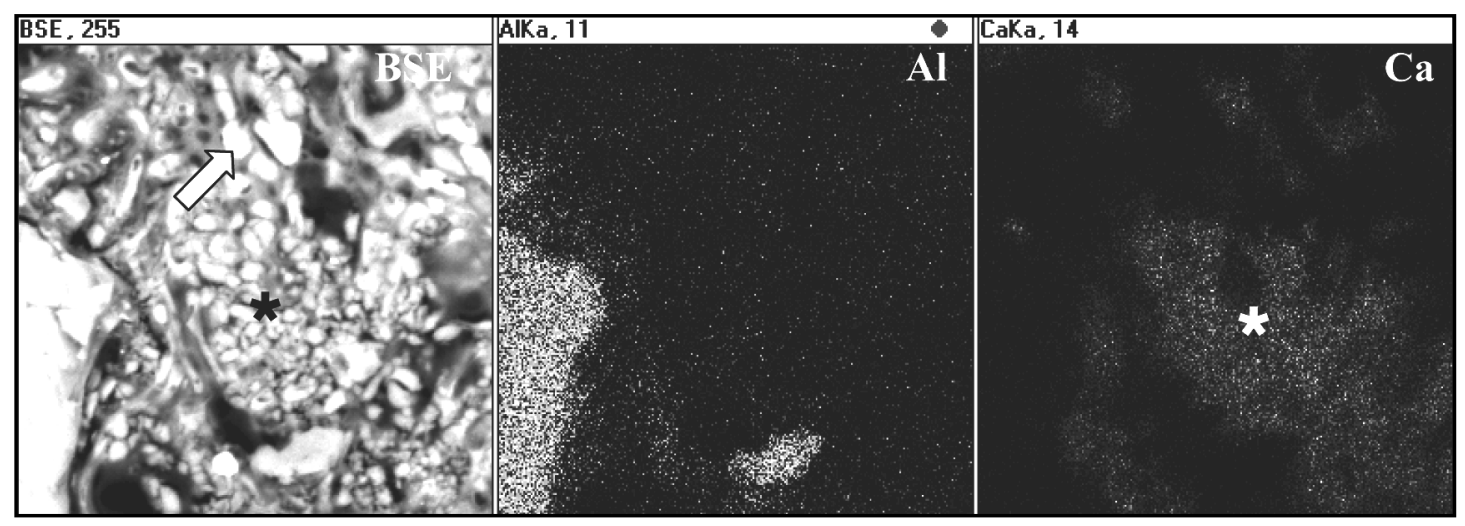

Figura 4. Imagen SEM-BSE y mapa de distribución espacial (EDX) de los elementos aluminio (Al) y calcio (Ca), mostrando la presencia de cristales de oxalato cálcico (asterisco) dispersos entre hifas fúngicas (flecha) pertenecientes a un talo liquénico.

Figure 4. SEM-BSE image and EDX spatial distribution map of aluminium (Al) and calcium (Ca) indicating the presence of calcium oxalate crystals (asterisk) between the fungal hyphae (arrow) of the lichen thallus. 
En este trabajo, se han definido tres fases en la colonización fúngica de las dolomías a través de la combinación de distintas microscopías (SEM-BSE y LTSEM) (Figura 5):
Through SEM-BSE and LTSEM, we were able to distinguish three well-defined stages of fungal colonization of the dolostones (Figure 5):
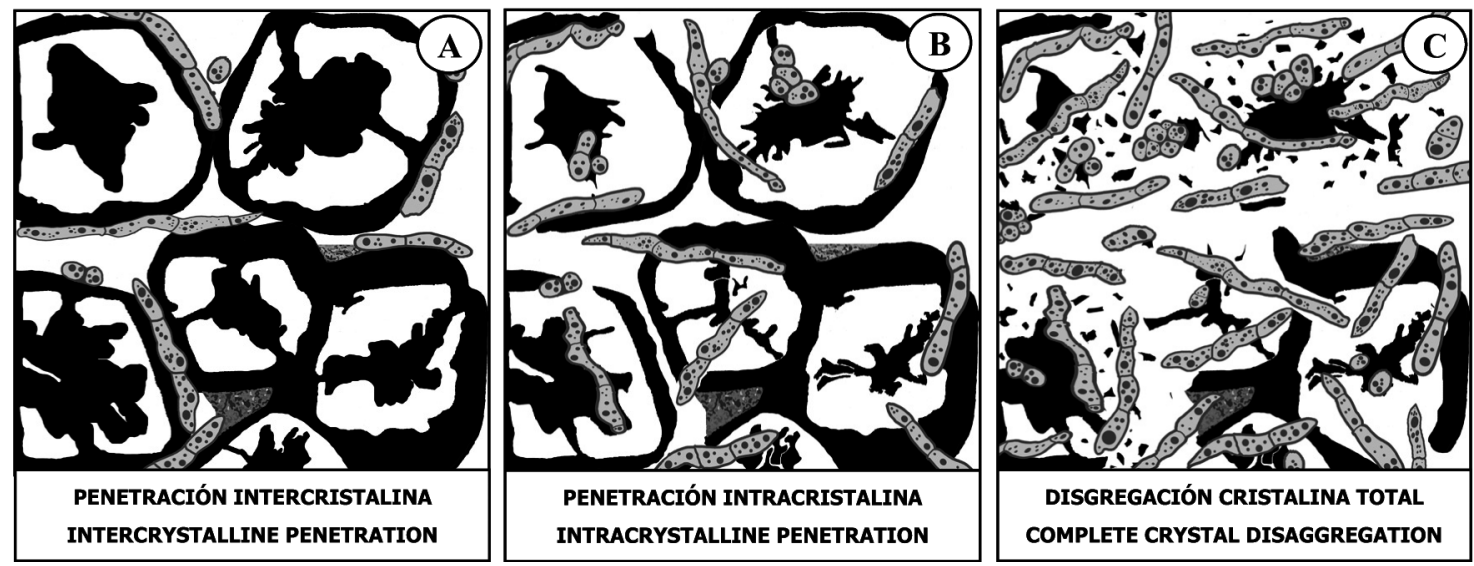

Figura 5. Diagrama de las tres fases de colonización fúngica en dolomías; A) Penetración intercristalina: los hongos penetran en las dolomías a través de la porosidad intercristalina propia de la roca; B) Penetración intracristalina: Los hongos llegan a penetrar finalmente en el interior de los cristales dolomíticos; C) Disgregación cristalina total: Los cristales dolomíticos aparecen reducidos a fragmentos minerales microdivididos y englobados en el interior de una masa de hongos.

Figure 5. Diagrams corresponding to the three fungal colonization stages observed on the dolostones; A) Intercrystalline penetration stage: the fungal hyphae penetrate the dolostone through the intercrystalline porosity of the rock; B) Intracrystalline penetration stage: the fungal hyphae penetrate inside the dolomite crystals; C) Complete crystal disaggregation stage: mineral crystals are reduced to microdivided mineral particles, which appear embedded in the fungal tangle.

1. Penetración intercristalina (Figura 5A): en una fase inicial, los hongos podrían aprovechar los espacios existentes entre los cristales dolomíticos para penetrar en el sustrato, probablemente en un intento por explorar nuevas áreas. La existencia de una porosidad intercristalina podría suponer una ruta de acceso al interior del sustrato lítico, facilitando de esta manera la colonización microbiana. Durante el crecimiento de las hifas del hongo se pueden generar tensiones que provoquen el desprendimiento de los cristales dolomíticos y su fragmentación en partículas minerales de menor tamaño $(5,7)$. La formación de estas partículas supone un incremento de superficie susceptible de ser colonizada y alterada por otro tipo de microorganismos litobiónticos $(21,22)$.

2. Penetración intracristalina (Figura 5B): en una segunda fase, los hongos alcanzan el interior de los cristales a través de la porosidad intercristalina. Los márgenes de estos cristales se pueden ver sometidos de forma incesante a la acción física y química de los hongos hasta que finalmente penetran en ellos y provocan graves daños sobre los cristales dolomíticos.

3. Disgregación cristalina total (Fig. 5C): en esta última fase, se detectaron los efectos de alteración más intensos. Esta caracterizada por la aparición muy frecuente de cristales dolomíticos reducidos a fragmentos minerales microdivididos y englobados en el interior de masas fúngicas. Este hecho nos hace pensar que la disgregación de
1. Intercrystalline penetration (Figure 5A): in an initial stage, fungal hyphae penetrate the rock substrate through spaces between mineral crystals, probably in an attempt to explore new areas. Clear intercrystalline porosity serves as an access route to the inner mineral crystals, promoting fungal invasion. The tensions generated during the course of this hyphal growth can provoke the detachment of mineral crystals and their fragmentation into mineral particles $(5,7)$, favouring further colonization of the dolostone by other lithobiontic organisms $(21,22)$.

2. Intracrystalline penetration (Figure 5B): in a second stage, through intercrystalline porosity, the fungal hyphae penetrate the crystals. Physical and chemical fungal activity acting on the crystals' margins could favour this penetration and the consequent intense effects on the dolomite crystals.

3. Complete crystal disaggregation (Figure 5C): in this last stage, greatest alteration effects were detected. Mineral crystals reduced to microdivided mineral fragments embedded in a fungal tangle were frequently observed. These microdivided mineral fragments can be considered as evidence of the previous existence of complete dolomi- 
los cristales podría tener lugar rápidamente una vez que los hongos penetran en su interior.

En las dolomías analizadas, se vio que la presencia y extensión de cada uno de los estados de colonización fúngica variaba en función de las características de textura específicas de los distintos tipos de dolomía. En el caso de las dolomías D-I, caracterizadas por una alta porosidad (inter e intracristalina), se pudo observar con la misma frecuencia los tres estados de colonización fúngica (Fig. 1B-Penetración intercristalina y penetración intracristalina; Fig. 1D-Disgregación cristalina total). La alta porosidad que las caracteriza, podría inducir la existencia de una amplia superficie de poros a través de la cual los hongos hayan podido acceder hasta que finalmente alcanzan el interior de los cristales dolomíticos. Por otro lado, la baja porosidad intracristalina de las dolomías tipo D-II, podría haber dificultado la penetración de los hongos al interior de los cristales, siendo la "penetración intercristalina", el estado predominante en estas dolomías (Fig. 2B). Por otro lado, en las dolomías D-III existe una estrategia de colonización diferente, solo limitada a grietas y fisuras ya existentes de la roca, probablemente como consecuencia de su baja porosidad (Fig. 3B). La mayor disgregación mineral se ha encontrado en aquellas muestras con una colonización fúngica más extendida (Fig. 1D). Consecuentemente, las dolomías con mayor porosidad, parecen mostrar una mayor biorreceptividad especialmente en fases iniciales de colonización y asociado a ello una mayor disgregación mineral. La colonización fúngica podría modificar estas características de textura, pero sólo cuando ésta tiene lugar de una manera extensiva. También es importante tener en cuenta que las características de textura pueden influir en la tasa y tipo de procesos de alteración físico-químicos que pueden tener lugar en la dolomía, por lo que podrían estar influyendo también de una manera indirecta en la biorreceptividad de la misma. Por ejemplo, el tamaño del poro condiciona los efectos de la cristalización de las sales (23, 24). Se ha visto que esta propiedad intrínseca también condiciona la cinética de capilaridad: la absorción de agua y la porosidad accesible son especialmente relevantes en la alteración llevada a cabo durante los ciclos de hielo-deshielo $(25,26)$.

Otras estrategias de colonización muy similares a las mostradas en este estudio, se han descrito en diferentes rocas caracterizadas también por una estructura cristalina con discontinuidades de magnitud apreciable entre los cristales. En mármol se ha observado que la falta de una porosidad intracristalina condiciona un modo de penetración intercristalino de los hongos, determinando así su alta resistencia al ataque fúngico debido a la dificultad de penetrar en el interior de los cristales calcíticos y dolomíticos (27). Sin embargo, en rocas carbonáticas de com- te crystals. Once fungi have invaded the mineral crystals, it seems they can cause their rapid disaggregation.

The presence and extent of the different stages were shown to depend directly on the specific textural features of the dolostone. In the $D-I$ dolostone characterized by its high porosity (inter and intracrystalline), the three fungal colonization stages were similarly frequent (Fig. $1 B$-intercrystalline penetration and intracrystalline penetration; Fig. 1D-complete crystal disaggregation). A high porosity could mean a large inner pore surface area and this could help fungal attack by providing an access route to the interior of the mineral. Moreover, the predominance of the "intercrystalline penetration" stage in the D-II dolostones, probably means that the low intracrystalline porosity makes it difficult to penetrate the dolomite crystals (Fig. 2B). Also, the low porosity of the D-III type dolostones could promote a different colonization strategy restricted to existing fissures and cracks in the rock (Fig. 3B). Samples with more extensive fungal colonization showed a greater extent of mineral disaggregation (Fig. 1D). In conclusion, dolostones of higher porosity seem to exhibit greater bioreceptivity, especially in the initial stages of colonization, accompanied by greater mineral disaggregation. When extensive, fungal colonization may also modify the rock's textural properties. In addition, these properties affect the rate and type of physico-chemical weathering processes that can take place in dolostone, such that these may also indirectly affect its bioreceptivity. For instance, pore size conditions the effects of salt crystallization (23, 24) and/or capillarity kinetics: water absorption and accessible porosity influence in the alteration by freeze-thaw cycles $(25,26)$.

Similar strategies to those observed here have been described for the fungal colonization of different rocks characterized by a crystalline structure with appreciable discontinuities among crystals. The lack of intracrystalline porosity in marble determines an intercrystalline mode of penetration and high resistance to fungal attack due to difficulties in penetrating the calcite and dolomite crystals (27). However, in carbonate rocks characterized by a homogeneous composition and structure, microbial colonization seems more related to active chemical dissolu- 
posición y estructura homogénea, la colonización microbiana se ha visto, más relacionada con una disolución química (28) que con una penetración a través de discontinuidades entre los cristales, y con un consecuente menor desprendimiento de fragmentos minerales.

Todos los resultados de este estudio sugieren que la petrofábrica de la roca (especialmente la magnitud y tipo de porosidad) podría ser un factor determinante de la biorreceptividad de las dolomías y, por tanto, de los procesos de alteración asociados a la colonización fúngica. En las dolomías utilizadas en construcciones históricas y artísticas es muy posible encontrar un comportamiento similar al mostrado en este estudio, por lo que es fundamental tener en cuenta las características de textura a la hora de elegir un material de construcción que pueda ser más resistente a la bioalteración. En este caso, para evitar la colonización microbiana sería recomendable el uso de dolomías de baja porosidad.

\section{CONCLUSIONES}

- La petrofábrica (textura y estructura) de las dolomías analizadas en este estudio, influye en la susceptibilidad que presentan a ser colonizadas por distintos microorganismos u organismos (biorreceptividad).

- La alteración de las dolomías depende directamente de la estrategia de colonización adoptada por los microorganismos, y por tanto podría ser una consecuencia directa de la biorreceptividad del sustrato lítico.

- La caracterización de propiedades intrínsecas de las rocas tales como la de textura es fundamental a la hora de elegir los materiales más adecuados para futuras construcciones, no sólo por su influencia en la resistencia a diferentes procesos físico-químicos, sino también en su propia biorreceptividad.

\section{AGRADECIMIENTOS}

Los autores quieren agradecer a la plantilla del servicio de microscopía electrónica del Centro de Ciencias Medioambientales por su asistencia técnica, a Ana Bernabéu por su ayuda en el estudio de porosimetría y a Ana Burton por la revisión del inglés. Este estudio ha sido subvencionado por la Comunidad de Madrid (S0505MAT/000094) y por un contrato I3P de postgraduado del CSIC (I3PCP6_06_00196). tion (28) than to penetration through discontinuities among crystals and is characterized by less detachment of mineral fragments.

Collectively, the findings of our study suggest that the rock petrofabric (especially the extent and type of porosity) could be a determining factor for the bioreceptivity of dolostone and consequently for weathering processes related to fungal colonization. We would expect similar behaviour in the dolostones used in historic buildings and sculptures, and recommend that to avoid bioweathering processes, textural features be taken into account when choosing the most suitable construction material. We propose the use of low porosity dolostones as building materials.

\section{CONCLUSIONS}

- The rock petrofabric of the dolostones analysed here (texture and structure) conditions the susceptibility of a rock for colonization by microorganisms or organisms (bioreceptivity).

- The weathering of these dolostones depends on the microbial colonization strategy, and is therefore a direct consequence of the bioreceptivity of the lithic substrate.

- Knowledge of the intrinsic properties of construction materials such as their textural features is essential for selecting the most suitable material for future constructions. These properties will not only determine their resistance to different physico-chemical processes but also their bioreceptivity.

\section{ACKNOWLEDGEMENTS}

The authors would like to thank the staff of the microscopy facility of the Centro de Ciencias Medioambientales for their technical assistance, Ana Bernabéu for her help with the porosimetry study and Ana Burton for revising the English. This study was supported by grant S0505MAT/000094 of the CAM and by a CSIC I3P postgraduate contract. 


\section{BIBLIOGRAFÍA / BIBLIOGRAPHY}

(1) Ascaso, C., García-del-Cura, M.A., De Los Ríos, A.: "Microbial Biofilms on Carbonate Rocks from a Quarry and Monuments in Novelda (Alicante, Spain)". In: Biodeterioration of Stone Surfaces, (eds. Clair, L.S., Seaward, M.), pp. 79-98, Kluwer Academic Publishers, Netherlands, (2004).

(2) Vegas Salamanca, J.: "El Cretácico en la Provincia de Segovia: Caracterización y degradación de rocas ornamentales y de cantería", Colección Becas de Investigación, Caja de Segovia (1998), pp. 54.

(3) Díez Herrero, A.: "El empleo de las rocas y los minerales en la arquitectura románica de la provincia de Segovia". En: Enciclopedia del Románico de Castilla y León. Segovia. Vol. 1, pp. 203-235, Fundación Santa María la Real, Aguilar de Campoo, España, (2007).

(4) De Los Ríos, A., Galván, V., Ascaso, C.: "In situ microscopical diagnosis of biodeterioration processes at the convent of Santa Cruz la Real", Segovia, Spain. Int. J. Biodet. Biodegr. 54 (2004), pp. 113-120.

(5) De Los Ríos, A., Ascaso, C.: "Contributions of in situ microscopy to the current understanding of stone biodeterioration". Int. Microbiol 8 (2005), pp. 181-188.

(6) Golubic, S., Friedmann, I., Schneider, J.: "The lithobiontic ecological niche, with special reference to microorganisms". J. Sediment. Petrol. 51 (1981), pp. 475-478.

(7) De Los Ríos, A., Wierzchos, J., Ascaso, C.: "Microhabitats and Chemical Microenvironments under Saxicolous Lichens Growing on Granite". Microbial. Ecol. 43 (2002), pp. 181-188.

(8) Papida, S., Murphy, W., May, E.: "Enhancement of physical weathering of building stones by microbial populations". Int. J. Biodet. Biodegr. 46 (2000), pp. 305-317.

(9) Gleeson, D.B., Clipson, N., Melville, K., Gadd, G.M., McDermott, F.P.: "Characterization of Fungal Community Structure on Weathered Pegmatitic Granite". Microbial. Ecol. 50 (2005), pp. 1-9.

(10) Guillitte, O.: "Bioreceptivity: a new concept for building ecology studies". Sci. Total Environ. 167 (1995), pp. 215-220

(11) Guillite, O. Dreesen, R.: "Laboratory chamber studies and petrographical analysis as bioreceptivity assessment tools of building materials". Sci. Total Environ. 167 (1995), pp. 365-374.

(12) Miller, A., Dionísio, A., Macedo, M.F.: "Primary bioreceptivity: A comparative study of different Portuguese lithotypes". Int. J. Biodet. Biodegr. 57 (2006), pp. 136-142.

(13) Prieto, B., Silva, B.: "Estimation of the potential bioreceptivity of granitic rocks from their intrinsic properties". Int. J. Biodet. Biodegr. 56 (2005), pp. 197-252.

(14) Prieto, P., Silva, B., Aira, N., Álvarez, L.: "Toward a definition of a bioreceptivity index for granitic rocks: Perception in the change in appearance of the rock". Int. J. Biodet. Biodegr. 58 (2006), pp. 150-154.

(15) Tucker, M.: "Techniques in Sedimentology". p. 394, Blackwell Science Publishers, Oxford, (1988).

(16) Tiab, D., Donaldson, E.C.: "Petrophysics: theory and practice of measuring reservoir rock and fluid transport properties". Gulf Publishing Company, Houston, Texas, (2004).

(17) Wierzchos, J., Ascaso, C.: "Application of back-scattered electron imaging to the study of the lichen-rock interface". Journal of Microscop. 175 (1994), pp. 54-59.

(18) De Los Ríos, A., Ascaso, C., Wierzchos, J.: "Study of lichens with different state of hydration by the combination of low temperature scanning electron and confocal laser scanning microscopies". Int. Microbiol. 2 (1999), pp. 251-257.

(19) Warscheid, Th., Braams, J.: "Biodeterioration of stone: a review". Int. J. Biodet. Biodegr. 46 (2000), pp. 343-368.

(20) Warscheid, Th., Becker, Th., Braams, J., Brüggerhoff, S., Gehrmann, C., Krumbein, W.E., Petersen, K.: "Studies on the temporal development of microbial infection of different types of sedimentary rocks and its effect on the alteration of the physico-chemical propierties in building material". In: Conservation of Stone and Other Materials Vol. I (ed. Thiel, M.-J.), pp. 303-310, E \& FN, London, (1993).

(21) De los Ríos, A., Grube, M., Sancho, L., G., Ascaso, C.: "Ultrastructural and genetic characteristics of endolithic cyanobacterial biofilms colonizing Antarctic granite rocks". FEMS Microbial Ecol. 59 (2007), pp. 386-395.

(22) Blackhurst R., Genge M.J., Kearsley A.T., Grady M.M.: "Cryptoendolithic alteration of Antarctic sandstones: pioners or opportunists?" J. Geophys. Res. 110 (2005), E12S24, doi: 10. 1029/2005JE002463.

(23) Benavente D., García-del-Cura, M.A., Fort, R., Ordóñez, S.: "Durability estimation of porous building stones from pore structure and strength". Eng. Geol. 74 (2004), pp. 113-127.

(24) Ordoñez, S., Fort, R., García-del-Cura, M.A.: "Pore size distribution in durability evaluation of porous limestones: Bateig Stone" (Alicante, Spain). Quarternary. J. Eng. Geol. 30 (1997), pp. 221-230.

(25) Thomachot, C., Matsuoka, N.: "Dilation of building materials submitted to frost action". In: Buildings Stone Decay: From Diagnosis to Conservation (eds. Prikryl, R., Smith, B. J.) 271, pp. 167-177, Geological Society, London, (2007).

(26) García-del-Cura, M.A., Benavente, D., Bernabéu, A., Fort, R., La Iglesia, A., Ordóñez, S.: "Microcrystalline limestone used as building stone: The Case of Gris Pulpis Stone". Mater. Construcc. 55 (2005), pp. 5-23.

(27) Sterflinger, K.: "Fungi as Geologic Agents. Geomicrobiol". J.17 (2000), pp. 97-124.

(28) Ascaso, C., Wierzchos, J., Souza-Egipsy, V., De Los Ríos, A., Rodrigues, J.D.: "In situ evaluation of the biodeteriorating action of microorganisms and the effects of biocides on carbonate rock of the Jeronimos Monastery" (Lisbon). Int. Biodet. Biodegr. 49 (2002), pp. 1-12. 